\title{
ANALISIS KEBIJAKAN SERTIFIKASI TERHADAP KINERJA GURU
}

\author{
${ }^{1}$ Muhamad Dzikry Alfath, ${ }^{2}$ Yayah Huliatunisa \\ ${ }^{1,2}$ Universitas Muhammadiyah Tangerang \\ Jalan Perintis Kemerdekaan I/33 Cikokol Kota Tangerang-Banten \\ 1muhamaddzikryalfath@gmail.com, ${ }^{2}$ yhuliatunisa13@gmail.com
}

\begin{abstract}
Abstrak
Penelitian ini bertujuan untuk mengetahui bagaimana kinerja guru yang bersertifikasi pendidik layak dalam melaksanakan tugas pendidik profesional, meningkatnya proses pembelajaran, meningkatnya kesejahteraan dan martabat guru di Sekolah Dasar Negeri Dukuh V Kecamatan Cikupa Kabupaten Tangerang, menggunakan metode penelitian kualitatif deskriptif, yaitu mengkaji dan menganalisis data secara objektif sesuai dengan data yang ditemukan dilapangan. Kemudian data yang terkumpul dari hasil penelitian di deskripsikan dalam bentuk kata-kata. Instrumen yang digunakan dalam penelitian ini adalah instrumen daftar pertanyaan wawancara, observasi dan dokumentasi. Kesimpulan penelitian bahwa kebijakan sertifikasi yang efektif dapat meningkatkan kinerja guru yang berdampak pada terwujudnya Pendidikan nasional yang bermutu.
\end{abstract}

Kata Kunci: sertifikasi, guru, kinerja guru

\begin{abstract}
This study aims to determine how the performance of teachers who are certified as educators is feasible in carrying out the duties of professional educators, improving the learning process, increasing the welfare and dignity of teachers in the Dukuh V Elementary School, Cikupa District, Tangerang Regency, using descriptive qualitative research methods, namely assessing and analyzing data objective according to the data found in the field. Then the data collected from the research results are described in the form of words. The instrument used in this study was a list of interview questions, observation and documentation. The research concludes that an effective certification policy can improve teacher performance which has an impact on the realization of quality national education.
\end{abstract}

Keywords: certification, teachers, teacher performance 


\section{PENDAHULUAN}

Semakin pesatnya perkembangan ilmu pengetahuan dan teknologi, serta tingginya arus globalisasi, berdampak munculnya persaingan dalam berbagai bidang kehidupan, termasuk pendidikan. Upaya menghadapi tantangan ini dibutuhkan sumber daya manusia berkualitas. Dalam dunia pendidikan salah satu cara yang ditempuh adalah menciptakan guru profesional dan memiliki kinerja baik agar mutu Pendidikan dapat mencapai tujuannya dengan optimal. Integritas diri serta kecakapan keguruan perlu ditumbuhkan serta dikembangkan secara terus menerus, karena guru memiliki tugas beragam yang implementasinya dalam bentuk pengabdian. Tugas tersebut meliputi bidang profesi, kemanusiaan dan bidang kemasyarakatan.

Peran guru dalam bidang pendidikan sangat strategis, bahkan sumber daya pendidikan lain seringkali kurang berarti apabila tidak disertai dengan kualitas guru yang memadai. Guru mempunyai peran sebagai profesional, jabatan ini menuntut peningkatan kecakapan dan mutu keguruan secara berkesinambungan. Guru berkualifikasi profesional adalah yang tahu secara mendalam tentang hal yang diajarkannya, cakap dalam cara mengajar efektif dan efisien serta mempunyai kepribadian. Guru juga harus memiliki kecakapan kerja baik dan kedewasaan berfikir tinggi, karena jabatan profesional guru merupakan posisi strategis dalam kehidupan dan pembangunan masyarakat. Guru harus dapat memantapkan posisi dan perannya melalui usaha-usaha mengembangkan kemampuan diri secara maksimal dan berkesinambungan. Hal ini didasarkan selain karena pendidikan berlangsung sepanjang hayat, sistem pengajaran, materi pengajaran dan penyampaiannya perlu terus dikembangkan, melalui upaya sistem pengembangan, sistem pengajaran, pembenahan isi serta teknologi organisasi materi pengajaran, pencarian pendekatan strategi, dan teknik pengajaran (perkembangan diri siswa) selalu perlu dikaji dan atau dikembangkan demi efektivitas serta efisiensi kerja Pendidikan.

Salah satu permasalahan pendidikan yang dihadapi oleh bangsa Indonesia adalah rendahnya mutu pendidikan pada setiap jenjang pendidikan dan satuan pendidikan khususnya pendidikan dasar. Beberapa faktor penyebabnya seperti rendahnya motivasi kerja guru, kedisiplinan, kemampuan dan kinerja guru. Baik tidaknya mutu hasil pendidikan bergantung pada motivasi dan kemampuan kerja guru. Jika motivasi kerja guru rendah, akan berdampak pada rendahnya kinerja guru dan mengakibatkan rendahnya mutu hasil pendidikan. Berkaitan dengan penyebab lain rendahnya motivasi kerja guru, karena masih banyak guru yang belum 
memenuhi kualifikasi pendidikan minimal, belum tercapainya budaya membaca bagi kalangan guru dan masih rendahnya kesejahteraan guru, sehingga menyebabkan rendahnya kinerja guru.

Perkembangan dunia pendidikan saat ini merupakan hal terpenting untuk meningkatkan sumber daya manusia di Indonesia. Oleh karena itu, pemerintah membuat program sertifikasi guru untuk meningkatkan keprofesionalan guru, kesejahteraan dan martabat guru seperti yang tercermin dalam Undang-Undang Nomor 14 Tahun 2005, pasal 8 adalah Guru wajib memiliki kualifikasi akademik, kompetensi, sertifikat pendidik, sehat jasmani dan rohani, serta memiliki kemampuan untuk mewujudkan tujuan pendidik nasional. Kualifikasi akademik dimaksud sebagaimana pasal 9 adalah melalui pendidikan tinggi program sarjana atau program diploma empat.

Guru yang telah melaksanakan tugas profesional berhak memperoleh penghasilan di atas kebutuhan hidup minimum dan jaminan kesejahteraan sosial. Penghasilan di atas adalah kebutuhan hidup minimum meliputi gaji pokok, tunjangan yang melekat pada gaji, serta penghasilan lain berupa tunjangan profesi, tunjangan fungsional, tunjangan khusus, dan maslahat tambahan yang terkait dengan tugasnya sebagai guru yang ditetapkan dengan prinsip penghargaan atas dasar prestasi.

Meskipun peningkatan kesejahteraan guru bukan merupakan tujuan, tetapi lebih sebagai instrumen untuk meningkatkan kinerja guru agar berdampak terhadap peningkatan mutu pendidikan nasional. Peningkatan kesejahteraan bagi guru yang telah memenuhi standar kualifikasi akademik dan kompetensi akan berfungsi meningkatkan kinerja sesuai yang diharapkan. Oleh karena itu, khusus untuk tunjangan profesi pendidik hanya akan diterima oleh guru profesional yang ditandai dengan kepemilikan sertifikat profesi guru melalui program sertifikasi.

Proses dalam program sertifikasi harus dilaksanakan secara obyektif, valid dan berkeadilan. Hal tersebut akan berpengaruh positif terhadap peningkatan kinerja guru dan selanjutnya akan berpengaruh positif terhadap peningkatan mutu pendidikan nasional. Pertanyaannya adalah apakah saat ini guru yang sudah lulus sertifikasi dan mendapat gelar guru profesional kinerjanya meningkat? Kenyataanya guru masih terpaku dengan kebiasaan lama yang belum mampu mengembangkan pengetahuan dan wawasannya dengan berusaha mencari tahu apa yang berkembang di dunia luar, baik itu dengan membaca buku atau 
mengakses internet sebagai sarana mudah untuk memperoleh informasi yang selalu berubah sejalan dengan perkembangan zaman.

Sekolah Dasar Negeri Dukuh V Kabupaten Tangerang merupakan salah satu lembaga pendidikan formal pada jenjang dasar, yang diselenggarakan untuk membangun fondasi pengetahuan peserta didik agar mampu dengan mandiri melanjutkan ke jenjang pendidikan yang lebih tinggi. Memiliki 472 peserta didik, jumlah guru 14 yang terdiri dari kepala sekolah, 10 guru kelas, 1 guru agama, 1 operator dan 1 penjaga sekolah. 5 guru berstatus sebagai Pegawai Negeri Sipil, 3 guru bersertifikasi termasuk kepala sekolah, 9 guru honorer dan 8 yang sudah mendapatkan bantuan operasional pendidikan yang di berikan oleh dinas pendidikan Kabupaten Tangerang.

Pelaksanaan kebijakan sertifikasi guru sejak tahun 2006 sampai sekarang ternyata masih menemui beberapa permasalahan, seperti di Sekolah Dasar Negeri Dukuh V Kabupaten Tangerang, pemahaman tujuan, fungsi dan manfaat sertifikasi guru belum sepenuhnya di pahami, bahkan masih terdapat guru yang secara kinerja belum baik. Temuan awal berdasarkan hasil identifikasi didapati bagaimana kebijakan sekolah berupaya mewujudkan mutu Pendidikan, dengan memberikan motivasi bagi peningkatan kinerja lebih tinggi terhadap guru bersertifikasi, serta memberikan pengembangan kompetensi, pemahaman tujuan dan pentingnya sertifikasi dalam meningkatkan kinerja bagi guru yang belum bersertifikasi.

Berdasarkan hal ini sertifikasi guru merupakan suatu langkah tepat untuk dapat meningkatnya motivasi, kemampuan dan kinerja guru. Sertifikasi akan menjadi acuan utama dalam memotivasi guru selain meningkatkan kompetensi profesionalnya, dan mendasari penelitian ini penting dan layak untuk dilakukan, karena upaya perbaikan apapun yang dilakukan, tidak akan memberikan sumbangan signifikan tanpa menyentuh tenaga pendidik dalam meningkatkan kualitas pembelajarannya.

\section{TINJAUAN TEORITIS}

Pendidikan merupakan investasi sumber daya manusia (SDM) jangka panjang yang mempunyai nilai strategis bagi kelangsungan peradaban manusia di dunia. Salah satu komponen penting dalam Pendidikan adalah guru. Guru dalam konteks Pendidikan mempunyai peranan besar dan strategis. Kebutuhan guru berkualitas semakin tinggi saat ini 
harus disikapi positif dengan meningkatkan program mutu Pendidikan yang ditawarkan. Oviyanti (2013).

Banyak faktor berpengaruh terhadap rendahnya kualitas pendidikan. Jika pendidikan di lihat sebagai suatu sistem, maka faktor yang turut mempengaruhi kualitas pendidikan tersebut, menurut Deming (Uno, 2012) adalah "input mentah siswa, lingkungan instruksional, proses pendidikan dan keluaran pendidikan”. Dalam proses pendidikan, di dalamnya terdapat aktivitas guru mengajar, peran serta siswa dalam belajar, sistem pengelolaan administrasi, serta mekanisme kepemimpinan kepala sekolah. (Erlina, dkk. 2017)

Guru saat ini menghadapi tantangan yang jauh lebih besar dari era sebelumnya. Guru menghadapi klien yang jauh lebih beragam, mata pelajaran lebih kompleks dan sulit, standar proses pembelajaran dan juga tuntutan capaian kemampuan berfikir siswa yang lebih tinggi. Penyebabnya karena (Andriani, 2010) transformasi besar pada aspek sosial, ekonomi, politik, dan budaya, didorong oleh perkembangan ilmu pengetahuan dan teknologi yang pesat, perubahan demografi, globalisasi dan lingkungan yang berdampak besar pada persekolahan dan profesionalisme guru.

Syukur (2012) berpendapat bahwa Pendidikan yang profesional akan dapat mengembangkan dan membentuk watak serta peradaban bangsa. Guru adalah bagian dari kesadaran sejarah pendidikan di dunia. Sebagai orang yang digugu dan ditiru seorang guru dengan sendirinya memiliki peran yang luar biasa dominannya bagi peserta didik. Dalam sebuah proses pendidikan guru merupakan satu komponen yang sangat penting, selain komponen lainnya, seperti tujuan, kurikulum, metode, sarana dan prasarana lingkungan dan evaluasi. Seiring dengan laju perkembangan pemikiran manusia yang melahirkan peradaban yang sangat cepat pertumbuhannya ditandai dengan kemajuan teknologi informasi yang kemudian dikenal dengan era global dengan konsekuensi globalisasi. Globalisasi menawarkan paradigma baru dalam pendidikan. Tentunya juga merupakan tantangan baru bagi guru profesional yang semakin hari semakin meningkat.

Dalam Kamus Besar Bahasa Indonesia, guru diartikan sebagai orang yang pekerjaannya (mata pencahariannya) mengajar. Dalam Undang-Undang Guru dan Dosen No. 14 Tahun 2005 pasal 2 bahwa:

"Guru dikatakan sebagai tenaga profesional yang mengandung arti bahwa pekerjaan guru hanya dapat dilakukan oleh seseorang yang mempunyai kualifikasi akademik, 
kompetensi dan sertifikasi pendidik sesuai dengan persyaratan untuk setiap jenis dan jenjang pendidikan tertentu."

Suprihatiningrum (2017) guru adalah pendidik profesional dengan tugas untuk mendidik, mengajar, membimbing, mengarahkan, melatih, menilai, dan mengevaluasi siswa pada pendidikan anak usia dini jalur pendidikan formal, pendidikan dasar, dan menengah.

Zahra Idris dan Lisma Jamal dalam Ramayulis (2016) guru (pendidik) adalah orang dewasa yang bertanggung jawab memberikan bimbingan kepada peserta didik dalam perkembangan jasmani dan rohaninya, agar mencapai tingkat kedewasaan (mampu mandiri sendiri) memenuhi tugasnya sebagai makhluk Tuhan, makhluk individu yang mandiri dan makhluk social. Selain itu menurut Rosnaningsih (2018) guru adalah salah satu faktor yang memegang peranan vital pada suatu proses pembelajaran.

Peran pendidikan dan guru sangat penting dan strategis, terutama dalam memberikan bimbingan, dorongan, semangat, fasilitas kepada masyarakat dan peserta didik untuk memperoleh ilmu pengetahuan dan keterampilan menggunakan teknologi. Selain itu, tidak kalah pentingnya adalah peran pendidikan dalam memberikan arahan dan bimbingan agar penguasaan teknologi tidak menjadi bumerang bagi masyarakat, yang disebabkan kurangnya penghayatan terhadap etika. Pendidikan dan guru dapat menumbuhkan pemahaman etika yang benar, agar kehidupan manusia tidak terancam oleh karena kemajuan teknologi itu sendiri. Manakala pendidikan mengisyarakatkan adanya keharusan peserta didik untuk menguasai teknologi, maka tentu tidak kalah pentingnya peran guru itu sendiri untuk lebih dulu menguasai ilmu pengetahuan dan teknologi agar dapat memberikan pengetahuan dan keterampilan teknologi ter-update kepada peserta didiknya. Oviyanti (2013).

Di abad 21, pekerjaan guru merupakan pekerjaan yang kompleks dan tidak mudah seiring dengan perubahan besar dan cepat pada lingkungan Sekolah yang didorong oleh kemajuan ilmu dan teknologi, perubahan demograsi, globalisasi dan lingkungan. Guru profesional tidak lagi sekedar guru yang mampu mengajar dengan baik, melainkan guru yang mampu menjadi pembelajar dan agen perubahan Sekolah, dan juga mampu menjalin dan mengembangkan hubungan untuk peningkatan mutu pembelajaran di Sekolahnya. Untuk itu, guru membutuhkan pengembangan profesional yang efektif, yaitu bimbingan. Pelaksanaan pembimbingan yang efektif perlu mempertimbangkan hal-hal yang mempengaruhi mutu hubungan pembimbingan, seperti struktur organisasi pembimbingan, kontrak kerja, mutu 
pembimbing, aktivitas dalam sesi-sesi awal sampai akhir pembimbingan. Untuk menguatkan fungsi dan manfaatnya, pembimbingan perlu diprogramkan. Hal ini membutuhkan perubahan struktur, budaya dan juga dukungan kepemimpinan dari Sekolah dan juga institusi terkait. Andriani (2010).

Kata "sertifikasi" dalam Kamus Besar Bahasa Indonesia adalah "penyertifikatan". (KBBI, 2002). Yamin (2006) Sertifikasi adalah "proses pemberian sertifikat pendidik untuk guru dan dosen atau bukti formal sebagai pengakuan yang diberikan kepada guru dan dosen sebagai tenaga profesional”. Sertifikasi guru juga merupakan upaya peningkatan mutu guru dibarengi dengan peningkatan kesejahteraan guru, sehingga dapat meningkatkan mutu pembelajaran dan mutu pendidikan di Indonesia secara berkelanjutan. Bentuk peningkatan kesejahteraan guru berupa tunjangan profesi sebesar satu kali gaji pokok bagi guru yang memiliki sertifikat pendidik. Tunjangan tersebut berlaku baik guru yang berstatus Pegawai Negeri Sipil (PNS) maupun guru yang berstatus non-PNS (Swasta). Di sini pengertian sertifikasi guru dan dosen dijelaskan sebagai suatu proses pemberian sertifikat pendidik untuk guru dan dosen atau bukti formal sebagai pengakuan yang diberikan kepada guru dan dosen sebagai tenaga pendidik profesional sebagai amanat Undang-Undang Republik Indonesia Nomor 20 Tahun 2003 tentang Sistem Pendidikan Nasional (Sisdiknas).

Yamin (2006) Sertifikasi dapat diartikan sebagai suatu proses pemberian, pengakuan kepada tenaga pendidik yang telah memiliki sejumlah kompetensi untuk melaksanakan pembelajaran sebagai pengakuan yang diberikan kepada guru dan dosen profesional pada lembaga pendidikan formal yang telah diselenggarakan oleh lembaga sertifikasi. Dengan dasar pengertian ini, maka sertifikasi guru (Mulyasa, 2009) adalah proses uji kompetensi yang dirancang untuk mengungkapkan penguasaan kompetensi seseorang sebagai landasan pemberian sertifikat pendidik.

Menurut Yamin (2013) menjelaskan bahwa sertifikasi guru adalah proses pemberian sertifikat pendidik untuk guru dan dosen atau bukti formal sebagai pengakuan yang diberikan kepada guru dan dosen sebagai tenaga profesional. Sejalan dengan pendapat Kunandar (2011) sertifikasi guru merupakan keniscayaan masa depan untuk meningkatkan kualitas dan martabat guru, menjawab arus globalisasi dan menyiasati sistem desentralisasi. Selain itu Suhana (2014) sertifikasi guru merupakan pemenuhan kebutuhan untuk meningkatkan kompetensi profesional. 
Sebagai tenaga pendidik, sertifikasi baru diberikan apabila persyaratan telah terpenuhi dengan keharusan memiliki: a) Kualifikasi akademik; b) Pendidikan dan pelatihan; c) Pengalaman mengajar; d) Perencanaan dan pelaksanaan pembelajaran; e) Penilaian dari atasan dan pengawas; f) Prestasi akademik; g) Karya pengembangan profesi; h) Keikutsertaan dalam forum ilmiah; i) Pengalaman organisasi di bidang pendidikan dan sosial; serta j) Penghargaan yang relevan dalam bidang pendidikan. (Muslich, 2007) Hal ini juga sebagaimana ditegaskan kembali dalam Pasal 28 ayat (1) PP RI No. 19 Tahun 2005 tentang Standar Nasional Pendidikan; dan Pasal 8 UU RI No 14, 2005 yang mengamanatkan bahwa guru harus memiliki kualifikasi akademik minimal D4/S1 dan kompetensi sebagai agen pembelajaran, yang meliputi kompetensi kepribadian, pedagogik, profesional, dan sosial. Kompetensi guru sebagai agen pembelajaran secara formal dibuktikan dengan sertifikat pendidik. Kualifikasi akademik minimum diperoleh melalui pendidikan tinggi, dan sertifikat kompetensi pendidik diperoleh setelah lulus ujian sertifikasi.

Sertifikasi guru bertujuan (Muslich, 2007) untuk meningkatkan tingkat kelayakan seorang guru dalam melaksanakan tugas pembelajaran secara lebih baik yang ditandai oleh pemberian sertifikat pendidik bagi guru yang telah dinyatakan lulus uji sertifikasi. Sertifikasi ini dilakukan agar tenaga pendidik dapat meningkatkan tingkat kelayakan sebagai seorang guru dalam melaksanakan tugas pembelajarannya ke arah yang lebih baik. (Samani, dkk, 2006) Senada dengan pendapat di atas, Wibowo, sebagaimana di kutip E. Mulyasa juga mengemukakan bahwa pemberian sertifikasi secara makro dilakukan agar dapat meningkatan kualitas layanan dan hasil pendidikan bertujuan untuk hal- hal yang berorientasi pada peningkatan mutu pendidikan. Harapan diharapkan akan tercapai pada masa-masa mendatang jika kegiatan sertifikasi guru masih menggunakan pola yang sama, yaitu menggunakan bentuk penilaian portofolio dengan mecakup sepuluh komponen, maka perlu dipikirkan upaya-upaya guru agar setiap guru dapat memperoleh kesempatan yang lebih luas, di antaranya melalui beberapa upaya. (Mulyasa, 2009)

Secara filosofis, motif dalam pengadaan sertifikasi dilaksanakan pemerintah agar mampu mengangkat harkat dan martabat guru di bidang kesejateraannya, serta meningkatkan hak-haknya secara seimbang dengan profesi lain yang lebih mapan kehidupannya. Melalui pemberdayaan ini, diharapkan akan tercipta perbaikan taraf hidup guru ke arah yang lebih adil, demokratis, serta tegaknya kebenaran dan keadilan di kalangan guru sebagai tenaga 
pendidik. Di sinilah nilai filosofis yang cukup esensial dalam meningkatkan mutu pendidikan sesuai dengan kebutuhan, perkembagan zaman, serta karakteristik lingkungan dan tuntutan grobal. (Mulyasa, 2009)

Seorang guru dituntut untuk dapat bekerja secara profesional. Pekerjaan guru adalah suatu profesi. Tingkat keberhasilan guru dalam menyelesaikan pekerjaannya disebut istilah level kinerja. Karwati (2013) mengemukakan bahwa: "Kinerja guru berkaitan dengan proses pembelajaran, yaitu kesanggupan atau kecakapan para guru dalam menciptakan suasana komunikasi yang edukatif antara guru dan peserta didik yang mencakup suasana kognitif, afektif dan psikomotorik"

Kinerja merupakan suatu kemampuan kerja atau prestasi kerja yang dicapai oleh seseorang. Jadi menurut bahasa, kinerja bisa diartikan sebagai prestasi yang nampak merupakan wujud keberhasilan kerja pada diri seseorang. Pada hakekatnya dapat dikatakan bahwa, prestasi yang sesungguhnya dicapai oleh seseorang itulah perwujudan dari kinerja (Erlina, dkk. 2017)

Kinerja merupakan terjemahan dari kata "performance" (Job Performance). Secara etimologis performance berasal dari kata "toperform" yang berarti menampilkan atau melaksanakan, sedang kata "performance" berarti the act of performing; execution (Webster Super New School and Office Dicionary). Menurut Mangkunegara dalam Suharsaputra (2013) menjelaskan bahwa kinerja (prestasi kerja) adalah hasil kerja secara kualitas dan kuantitas yang dicapai oleh seorang pegawai dalam melaksanakan tugasnya sesuai dengan tanggung jawab yang diberikan kepadanya. Sedangkan menurut Supardi (2014) kinerja guru merupakan kemampuan dan keberhasilan guru dalam melaksanakan tugas-tugas pembelajaran yang ditunjukkan oleh indikator-indikator: (1) kemampuan menyusun rencana pembelajaran, (2) kemampuan melaksanakan pembelajaran, (3) kemampuan melakukan hubungan antar pribadi, (4) kemampuan melaksanakan penilaian, (5) kemampuan melaksanakan pengayaan, (6) kemampuan melaksanakan remidial.

Sertifikasi yang akan dilaksanakan hendaknya memperhatikan kriteria dan persyaratan yang harus dipenuhi oleh guru. Hanya guru yang memenuhi persyaratan dan kriteria tertentu saja yang boleh mengikuti uji kompetensi untuk memperoleh sertifikat. Sertifikat diberikan hanya kepada guru yang benar-benar memenuhi persyaratan dan kriteria serta lulus seleksi secara transparan dan akuntabel. Secara teoritis, proses sertifikasi yang dilakukan dengan 
benar akan berkontribusi positif terhadap mutu pendidikan. Mutu pendidikan adalah keadaan baik-kurang baiknya kondisi, layanan dan hasil pendidikan di suatu sekolah berdasarkan kriteria ideal dan harapan masyarakat. Kondisi, layanan, dan hasil pendidikan yang sesuai atau melebihi harapan pihak yang berkepentingan adalah indikator utama sekolah bermutu. (Hermawan, 2017)

\section{METODE PENELITIAN}

Penelitian ini menggunakan metode kualitatif deskriptif. Sugiyono (2018) metode penelitian kualitatif adalah metode penelitian yang berlandaskan pada filsafat, yang digunakan untuk meneliti pada kondisi ilmiah (eksperimen) dimana peneliti sebagai instrument, teknik pengumpulan data dan analisis yang bersifat kualitatif lebih menekan pada makna. Penelitian ini termasuk penelitian deskriptif atau studi eksplorasi, karena bertujuan menggambarkan keadaan atau fenomena yang terjadi dilapangan. Arikunto (2010) penelitian deskriptif adalah suatu penelitian yang bertujuan untuk menggambarkan atau memaparkan sesuatu hal, misalnya keadaan, kondisi, situasi, peristiwa, kegiatan dan lain-lain. Metode ini dianggap sangat cocok karena bertujuan mengumpulkan informasi mendalam melalui analisis sistematis mengenai kebijakan sertifikasi terhadap kinerja guru di Sekolah Dasar Negeri Dukuh V Cikupa Kabupaten Tangerang.

Sumber data dalam penelitian merupakan subjek dari mana data dapat diperoleh. Dalam penelitian ini data dikelompokkan menjadi data primer dan data skunder. Data primer adalah data yang diperoleh langsung dari lapangan berupa hasil karangan sederhana dan wawancara kepada responden. Adapun sumber data primer dalam penelitian ini adalah kepala sekolah dan guru yang sudah bersertifikasi. Data sekunder adalah data-data yang sudah tersedia di tempat yang akan diteliti seperti surat-surat, gambar, foto yang berkaitan dengan penelitian ini.

Data yang terkumpul kemudian dilakukan analisis data menggunakan teori Milles dan Huberman melalui reduksi data, disajikan sampai menghimpun dan menyimpulkan data terpilih sesuai kebutuhan penelitian. Analisis adalah proses mencari dan menyusun secara sistematis data yang diperoleh dari hasil wawancara, catatan lapangan, dan bahan-bahan lain, sehingga dapat mudah dipahami dan temuannya dapat diinformasikan kepada orang lain. Analisis data dilakukan dengan mengorganisasikan data, menjabarkannya ke dalam unit-unit, 
melakukan sintesa, menyusun ke dalam pola, memilih mana yang penting dan yang akan di pelajari, dan membuat kesimpulan atas jawaban-jawaban yang diberikan informan dengan menggunakan analisis domain.

Kualitas atau uji keabsahan data dilakukan melalui triangulasi teknik dan sumber, yakni melihat dan membandingkan data hasil wawancara antara informan satu dengan lainnya dan dengan suatu dokumen yang berkaitan.

\section{HASIL DAN PEMBAHASAN}

Hasil penelitian Kebijakan sertifikasi guru di Sekolah Dasar Negeri Dukuh V Kabupaten Tangerang, didapati bahwa kelayakan guru dalam melaksanakan tugas sebagai pendidik profesional, meningkatkan proses pembelajaran, meningkatkan kesejahteraan guru, serta meningkatkan martabat guru, dalam rangka meningkatkan kinerja guru dalam mewujudkan Pendidikan nasional bermutu melalui berbagai aspek, adalah sebagai berikut:

Aspek sertifikasi guru yaitu pemahaman tentang sertifikasi guru. Dari hasil pemahaman dan respon guru guru terhadap kebijakan sertifikasi sudah sangat baik.

Aspek sertifikasi guru yang ke dua yaitu penyelenggaraan sertifikasi guru. Penyelenggaraan sertifikasi guru di Sekolah Dasar Negeri Dukuh V dilakukan sejak tahun 2007. Guru dengan inisial (JS) mendapatkan sertifikasi sejak tahun 2008 dan guru dengan inisial (CW) mendapatkan sertifikasi sejak tahun 2013.

Aspek sertifikasi guru yang ke tiga yaitu syarat dan manfaat sertifikasi guru. Pemahaman guru tentang syarat dan manfaat kebijakan sertifikasi guru sangat baik. Guru mengetahui syarat mengikuti sertifikasi guru adalah berstatus Pegawai Negeri Sipil, memiliki ijazah S1, memiliki NUPTK, mengikuti penilaian portofolio, mengikuti UKG. Serta manfaat mengikuti sertifikasi guru adalah dapat meningkatkan kompetensi dan guru menjadi lebih profesional dalam mengajar.

Aspek sertifikasi guru yang ke empat yaitu tujuan sertifikasi guru. Hasil pemahaman dan respon guru terhadap kebijakan sertifikasi sudah sangat baik. Tujuan kebijakan sertifikasi guru dipahami untuk meningkatkan kompetensi guru dalam mengajar dan kebijakan sertifikasi ini disadari sangat efektif dalam peningkatan mutu pendidikan.

Kinerja guru dalam penelitian ini hanya memfokuskan pada empat aspek kompetensi guru yaitu kompetensi pedagogik, kompetensi kepribadian, kompetensi profesional dan 
kompetensi sosial yang bertujuan untuk mengetahui kompetensi guru yang sudah bersertifikasi.

Aspek kinerja guru yaitu kompetensi pedagogik. Hasil kompetensi pedagogik guru di Sekolah Dasar Negeri Dukuh V cukup baik. Hasil kepekaan guru serta kompetensi yang dimiliki dalam melakukan evaluasi hasil belajar siswa, melalui soal-soal atau test di akhir pembelajaran yang bertujuan untuk mengetahui pembelajarannya sudah tercapai atau tidak, sangat terlihat baik.

Aspek kinerja guru yang ke dua yaitu kompetensi kepribadian. Kompetensi kepribadian guru di Sekolah Dasar Negeri Dukuh V cukup baik. Guru dapat menampilkan diri sebagai pribadi yang jujur, berakhlak mulia dan teladan bagi peserta didik dan dilingkungan masyarakat dengan berprilaku yang sesuai dengan norma-norma yang sudah ditetapkan dan menghindari norma-norma yang dilarang oleh etika profesi.

Aspek kinerja guru yang ke tiga yaitu kompetensi profesional. Kompetensi profesional guru di Sekolah Dasar Negeri Dukuh V ini cukup baik. Guru selalu berusaha melaksanakan pembelajaran menggunakan RPP, dapat memahami karakteristik peserta didik melalui proses pembelajaran terarah dan sistematis, serta memanfaatkan teknologi pada saat pembelajaran berlangsung.

Aspek kinerja guru yang ke empat yaitu kompetensi sosial. Kompetensi sosial guru di Sekolah Dasar Negeri Dukuh V ini cukup baik. Guru selalu memberikan contoh-contoh yang dapat menumbuhkan sikap sosial yang baik dan saling menghargai sesama siswa, guru selalu membangun komunikasi dengan baik, bersikap yang sopan sesuai kode etik guru dan selalu menjaga silaturahmi dengan siapapun, baik dengan siswa, wali siswa, sesama guru dan masyarakat.

\section{SIMPULAN DAN SARAN}

Berdasarkan penelitian yang telah dilaksanakan dapat disimpulkan bahwa kebijakan sertifikasi ini sangat efektif dalam peningkatan mutu pendidikan. Hasil analisis dengan adanya kebijakan sertifikasi terhadap guru di Sekolah Dasar Negeri Dukuh V Kabupaten Tangerang, bahwa kinerja guru, kompetensi keperibadian guru, kompetensi professional guru, dan kompetensi social guru cukup baik, hal tersebut dapat dilihat dari: Indikator capaian kemampuan guru dalam memahami karakteristik peserta didik, lebih berkompeten 
dalam memahami setiap karakter peserta didik, guru menampilkan diri sebagai pribadi yang jujur, berakhlak mulia dan teladan bagi peserta didik dan dilingkungan masyarakat dengan berprilaku yang sesuai dengan norma-norma yang sudah ditetapkan dan menghindari normanorma yang dilarang oleh etika profesi, guru selalu berusaha melaksanakan pembelajaran menggunakan RPP yang disesuaikan dengan peserta didiknya agar pembelajaran terarah dan guru sering memanfaatkan teknologi pada saat pembelajaran berlangsung agar siswa lebih mudah memahaminya, dan guru selalu memberikan contoh-contoh yang dapat menumbuhkan sikap sosial yang baik dan saling menghargai sesama siswa, guru selalu membangun komunikasi dengan baik, bersikap yang sopan sesuai kode etik guru, dan selalu menjaga silaturahmi dengan siapapun baik dengan siswa, wali siswa, sesama guru dan masyarakat.

Berdasarkan hasil penelitian, peneliti memandang penting untuk menyampaikan saran, dengan tujuan agar kinerja guru yang baik menjadi budaya dalam upaya meningkatkan mutu Pendidikan. Saran tersebut adalah:

1. Bagi guru, sebagai motivasi untuk meningkatnya kinerja guru, meningkatkan kualitas pembelajaran dan tercapainya mutu Pendidikan dengan maksimal.

2. Bagi sekolah, sebagai lembaga pendidikan hendaknya dapat membina guru yang sudah bersertifikasi untuk semakin meningkatkan kinerjanya, dan memotivasi melalui pengembangan kompetensi bagi guru yang belum bersertifikasi.

3. Bagi pembaca, penelitian ini dapat menambah wawasan dan bahan referensi bagi penelitian selanjutnya.

\section{DAFTAR PUSTAKA}

Andriani, Dwi Esti. (2010). Pengembangan Profesionalitas Guru Abad 21 Melalui Program Pembimbingan yang Efektif. Jurnal Manajemen Pendidikan, Volume 6. No. 2, Oktober 2010. Jurnal Manajemen Pendidikan FIP UNY Yogyakarta.

Arikunto, S. (2010). Prosedur Penelitian: Suatu Pendekatan Praktik. Jakarta: Rineka Cipta. Departemen Pendidikan dan Kebudayaan RI, Kamus Besar Bahasa Indonesia (Jakarta: Balai Pustaka, 2002), 1052

Erlina, dkk. (2017). Kinerja Guru Bersertifikasi dalam Meningkatkan Pembelajaran pada Madrasah Aliyah Negeri (MAN) Beureunuen Kabupaten Pidie. Jurnal Magister Administrasi Pendidikan Pasacarsajan Universitas Syiah Kuala. ISSN 2302-0156 pp. 147-153 vol. 5, No.3 Agustus 2017. 
Indonesian Journal of Elementary Education

Vol. 2, No.1, Desember 2020

E-ISSN: 2722-6689

http://jurnal.umt.ac.id/index.php/lJOEE

Hermawan, Daman. (2017) Profesionalisasi dan Sertifikasi Guru dalam Meningkatkan Mutu Pendidikan. Jurnal Administrasi Pendidikan UPI. Vol. 5 No. 1.

Karwati, et al. (2013). Kinerja dan Profesionalisme Kepala Sekolah: Membangun Sekolah yang Bermutu. Alfabeta, Bandung.

Kunandar. (2011). Guru Profesional Implementasi Kurikulum Tingkat Satuan Pendidikan (KTSP) dan Sukses dalam Sertifikasi Guru. Jakarta: PT Raja Grafindo Persada.

Muslich, M. (2007). Sertifikasi Guru Menuju Profesionalisme Pendidik. Jakarta: Bumi Akasara.

Mulyasa. (2009). Standar Kompetensi dan Sertifikasi Guru. Bandung: Remaja Rosdakarya.

Oviyanti, Fitri. (2013). Tantangan Perkembangan Pendidikan Keguruan di Era Globalisasi.

Jurnal Pendidikan Islam, Volume 7, No. 2, Oktober. Jurnal Pendidikan Agama Islam IAIN Raden Fatah Palembang.

Ramayulis. (2016). Profesi Dan Etika Keguruan. Jakarta: Kalam Mulia.

Rosnaningsih, A. (2017). Perencanaan Pembelajaran. Tangerang: Pupa Media.

Samani, dkk. (2006). Mengenal Sertifikasi Guru di Indonesia. (Jakarta: SIC dan Assosiasi Peneliti Pendidikan Indonesia).

Sugiyono. (2018). Metode Penelitian Kuantitatif, Kualitatif, dan $R \& D$. Bandung: Alfabeta.

Suhana, C. (2014). Konsep Strategi Pembelajaran. Bandung: PT Refika Aditama.

Suharsaputra, U. (2013). Administrasi Pendidikan. Bandung: PT Refika Aditama.

Suprihatiningrum, J. (2017). Guru ProfesionalPedoman Kinerja, Kualifikasi, \& Kompetensi Guru. Yogyakarta: Ar-Ruzz Media.

Supardi. (2014) Kinerja Guru. Jakarta. Raja Grafindo Persada.

Syukur, Sf Mahlaih. (2012). Profesionalisme Guru dan Globalisasi (Karakter Guru Profesional di Era Global). Proceeding Seminar Nasional Tahun 2012. ISBN: 978602-18235-0-7. Pascasarjana Universitas Wahid Hasyim Semarang.

Uno, Hamzah B (2012) Perencanaan Pembelajaran. Bumi Aksara, Jakarta.

Yamin, Martinis. (2006). Sertifikasi Profesi Keguruan di Indonesia dilengkapi UU No. 14 Tahun 2005 Tentang Guru dan Dosen. Cet. I, Jakarta: Gaung Persada Press. (2013). Sertifikasi Profesi Keguruan di Indonesia. Ciputat: GP Press Group. 